\title{
Zsadányi, Edit. 2015: Gendered Narrative Subjectivity: Some Hungarian and American Women Writers. Frankfurt am Main: Peter Lang. 149 pp.
}

\author{
Reviewed by Agatha Schwartz*, University of Ottawa, Canada
}

In the present volume, Edit Zsadányi, of Eötvös Loránd University in Budapest and a wellknown name in Hungarian gender studies, proposes an analysis of feminine subjectivity construction in selected narratives by women writers of Hungarian and American literature through the critical lenses of narratology, linguistics, feminism, and postmodernism. As stated in the Introduction, Zsadányi aims at bridging the (seeming) contradiction between feminist and postmodern definitions of the subject. She uses the examples of her selected women writers to show that the feminine subject in these texts is constructed beyond the obvious gender identification through the narrator or the characters, and she searches instead for rhetorical figures, repetitions or omissions in the text to demonstrate how women writers transgress the apparent contradiction between the feminist search for a strong (feminine) subject and the (post)modern deconstruction of this subject.

The book is divided into six chapters preceded by an Introduction and followed by a Conclusion, a list of works cited, an Appendix featuring three embroideries by Anna Lesznai, and an Index. With the exception of Chapter One, which offers an overview of selected theorists (including Jacques Derrida, Judith Butler, Rosi Braidotti, Louis Althusser, Paul de Man, Mieke Bal, Teresa de Lauretis, Linda Hutcheon, and others), most chapters focus either on Hungarian or American women writers. Only Chapters Five and Six present a comparison between selected writers from these two national literatures. Most chapters include contemporary writers, with the exception of Chapter Two, in which only Hungarian writers from the early twentieth-century are discussed. As the author states in her Acknowledgments, four out of the five thematic chapters in the book were published in earlier versions either in journals or in essay collections, which explains the overall impression that the book presents a loosely connected collection of independent essays rather than a coherent monograph. What unites the analysis, however, is a narratological and linguistic emphasis on the construction of the decentered feminine subject through language.

Chapter Two, "Figures of Narrative Subjectivity in the Works of Margit Kaffka, Emma Ritoók, Jolán Földes and Anna Lesznai," is dedicated entirely to Hungarian modernist writers, with an emphasis on the four female authors listed in its title. Zsadányi regretfully states that most of these and other Hungarian women writers from the early twentieth-century, with the

*agatha.schwartz@uottawa.ca

(cc) $\mathrm{Br}$

ULIS D-Serle
New articles in this journal are licensed under a Creative Commons Attribution 4.0 International License.

This journal is published by the University Library System of the University of Pittsburgh as part of its D-Scribe Digital Publishing Program and is cosponsored by the University of Pittsburgh Press 
Schwartz, Agatha. "Zsadányi, Edit. 2015: Gendered Narrative Subjectivity: Some Hungarian and American Women Writers. Frankfurt am Main: Peter Lang. 149 pp." Hungarian Cultural Studies. e-Journal of the American Hungarian Educators Association, Volume 10 (2017) DOI: 10.5195/ahea.2017.302

exception of Kaffka, have been ignored by mainstream literary history and that it is only in the past couple of decades that they have attracted some critical attention. It therefore comes as a bit of a surprise to the reader when suddenly, in the middle of a section titled "The Trope of Enumeration and Feminine Self-Realization" (my emphasis) in this chapter, about three pages are devoted to Dezső Kosztolányi, a canonical male author of Hungarian modernism. This jump is all the more bewildering as the figure analyzed in Kosztolányi's short story "Motorcsónak" ['Motorboat'] is a man. Zsadányi does not justify this insertion, which does not help with the chapter's topical coherence either. This incoherence further deepens as additional brief (and from the point of view of the chapter's focus, unnecessary) comparisons with writers and texts not previously introduced appear, too, such as Cécile Tormay (to most non-Hungarian readers an unknown name that would have needed further introduction) and Gertrude Stein. Moreover, the chapter introduces two new critics, Griselda Pollock and Rita Felski, in addition to the concept of écriture féminine (without, however, mentioning its key theoreticians of the 1970s like Hélène Cixous and Luce Irigaray), neither of which were previously mentioned in the first, theoretical chapter.

Chapter Two leaves the reader with a further impression of imbalance regarding the importance paid to one writer over the others given that eleven pages (out of a total of thirty-two) are devoted to Anna Lesznai's poetry and her embroidery whereas a bare two pages deal with Jolán Földes. I would also disagree with some points in the chapter's conclusion, namely that the women writers analyzed in it "do not imagine alternative lives" for women and that they "work toward the emergence of a decentered feminine subjectivity" (63). Whereas this may certainly be true for some of the narratives by Kaffka and Ritoók, it is definitely not the case when it comes to other texts by the same authors, in particular Ritoók's novel Egyenes úton, egyedül ['On a Straight Path, Alone'] or Kaffka's Állomások ['Stations'] and Színek és évek ['Colors and Years']. In all three novels the possibility of a different life for women is very much expressed and an ambiguity is formulated regarding the centered subject of the emancipated woman who looks toward a brighter future as opposed to that of the (post)modern decentered one.

Chapter Three, "Narrative Conceptions of Identity and Otherness in the Works of Contemporary Hungarian Female Writers," turns to contemporary Hungarian women writers Virág Erdős, Zsuzsa Rakovszky, Noémi Szécsi, Alaine Polcz, Viktória Köves, Zsuzsa Forgács and Margit Halász. This chapter is much stronger regarding the linking to the theories introduced earlier in the book in that it is looking at expressions of feminine identity through language and considering the simultaneous presence of a decentered subject and women's subordinate position while also allowing for the voicing of a strong femininity. However, there are some attempts of establishing intertextual parallels, such as with Marquis de Sade, that seem disruptive to the overall flow of the text and thus arbitrary and ultimately out of place. Zsadányi considers the writing of the above women authors as less postmodern, i.e., more "traditional" than the works of their much more famous male contemporaries, such as Péter Esterházy, but she sees their value precisely in their ways of inserting interruptions into a seemingly coherent narrative. She interprets these interruptions as expressions of "feminine otherness inherently excluded from Western language and culture" (90), a conclusion that unfortunately ends with a note of generalization (what exactly is "Western language and culture," in particular when formulated in the singular?), thus potentially leaving the reader with the impression that the construction and exclusion of the feminine Other does not apply to non-Western languages and cultures. 
Schwartz, Agatha. "Zsadányi, Edit. 2015: Gendered Narrative Subjectivity: Some Hungarian and American Women Writers. Frankfurt am Main: Peter Lang. 149 pp." Hungarian Cultural Studies. e-Journal of the American Hungarian Educators Association, Volume 10 (2017) DOI: 10.5195/ahea.2017.302

Chapter Four, "Decentered Subjectivity in Gertrude Stein's Three Lives and Kathy Acker's Don Quixote," is the shortest in the volume and, as the title suggests, in it the author moves from Hungarian to American literature. This chapter offers a succinct and convincing analysis of subjectivity formation in two examples of "experimental fiction" (91) written by women, in which the boundaries between the subject and discourse become blurred as they can be found in figures of speech as much as in figures of characters. Here Zsadányi convincingly shows how one of Stein's main characters, Lena, although practically voiceless and destroyed by the grand narratives of marriage and motherhood, echoes in the adjective "gentle" associated with her name as it keeps reverberating throughout the remaining text after her death and thus marks the discourses that oppressed her and that outlive her. Acker's self-referential and selfconstructing and deconstructing narrative presents a criticism of heteronormativity through a female Don Quixote's journey through American history in what Zsadányi calls "an[sic] unique and open concept of narrative" (100).

Chapters Five and Six employ a comparative approach in that they look for similar issues of representation and subjectivity formation, each in two narratives, one by an American and one by a Hungarian woman writer. Chapter Five analyzes two narratives that both deal with lesbian desire and identities, hence the title "Speaking from the Margin: Gertrude Stein's Tender Buttons and Agáta Gordon's Kecskerúzs ['Goat Rouge']." Both texts, one belonging to American modernism and one that could be easily classified as a major example of Hungarian postmodern writing, deconstruct the concept of stable sexual identities through their narrative form and language as much as through their strategies of representation. These texts, Zsadányi argues, also play with the implied reader as, ultimately, it is not only the reader who reads the text, but the text, too, with its playful destabilization of fixed identity positions and narrative linearity, offers the reader a mirror in which we, the readers, can begin to question our own fixed identities and, to use Homi K. Bhabha's famous formulation, "emerge as the others of our selves" (The Location of Culture; London: Routledge, 1994, 209). One point of criticism I would raise regarding this chapter, as I did concerning Chapter Two, is that the theories by Culler, Iser, Fish and others in this chapter, too, should have been introduced along with those of others in Chapter One.

Chapter Six, "Detailed Description as Subjectivity Formation: Jhumpa Lahiri's The Namesake and Jolán Földes' The Street of the Fishing Cat," takes a contemporary narrative by an American writer and compares it to a work by Jolán Földes, a Hungarian writer from the first half of the twentieth century who was already introduced in Chapter Two. While an interesting analysis of an intertextual narrative (as it contains numerous references to Gogol's The Overcoat), it is really not clear how The Namesake is supposed to fit with the purpose of Zsadányi's book given that in her Introduction she clearly states that her aim is "to examine the issue of representing feminine identities" (9, my emphasis). The Namesake, however, is about the identity qualms of Gogol, the son of Indian immigrants. Could we therefore read the wrong use of the pronoun "her" ("her American girlfriend" instead of "his") on page 125 as a Freudian slip on the part of the author to add a gender dimension to Gogol's identity search and thus make this analysis better fit the rest of the book? Unfortunately, Földes, similarly to Zsadányi's treatment in Chapter Two, is again shortchanged of a more thorough analysis as she is only given a page and a half. It would have been a better way of organizing the book's chapters to entirely remove Földes from Chapter Two and give her more adequate space in this chapter, although even that would not solve the problem of The Namesake's not fitting into the overall purpose of Zsadányi's study. 
One general criticism I would raise against Zsadányi's book is that she uses secondary literature too sparingly, in particular when it comes to Hungarian women writers. She only references Hungarian sources on the same and ignores other relevant scholarship on Hungarian women writers in North America, such as Louise Vasvári on Alaine Polcz, Judith Szapor on Emma Ritoók, Fiona Stewart on Ritoók and Lesznai, or my own Shifting Voices: Feminist Thought and Women's Writing in Fin-de-Siècle Austria and Hungary (2008). While this could perhaps be somewhat justified had Zsadányi's book been published in Hungarian and intended exclusively for Hungarian readers, for a publication in English it is unacceptable.

Overall, however, Gendered Narrative Subjectivity is a well-written and important work as it gives Hungarian women writers, most of whom are even less known abroad than they are in their home country, an international and intercultural exposure and thus puts them in line with major literary movements while demonstrating the applicability of major theories to their writings. For this purpose, too, it would have also been helpful for the benefit of readers less familiar with the authors discussed to include a section with short biographies of each of these women writers. 